\title{
Early appearance and possible functions of non-neuromuscular cholinesterase activities
}

\section{Carla Falugi * and Maria G. Aluigi}

Dipartimento per lo studio del Territorio e delle sue Risorse, Laboratory of Experimental Embryology, Università di Genova, Genova, Italy

\section{Edited by:}

Hermona Soreq, The Hebrew

University of Jerusalem, Israel

\section{Reviewed by:}

Yuri B. Shmukler, N.K.Koltzov Institute of Developmental Biology,

Russia

Zoltan-Rakonczay, University of

Szeged, Hungary

\section{*Correspondence.}

Carla Falugi, Dipartimento per lo studio del Territorio e delle sue

Risorse, Laboratory of Experimental Embryology, Università di Genova,

Corso Gastaldi, 16132 Genova, Italy. e-mail: falugi@unige.it
The biological function of the cholinesterase (ChE) enzymes has been studied since the beginning of the twentieth century. Acetylcholinesterase plays a key role in the modulation of neuromuscular impulse transmission in vertebrates, while in invertebrates pseudo cholinesterases are preeminently represented. During the last 40 years, awareness of the role of ChEs role in regulating non-neuromuscular cell-to-cell interactions has been increasing such as the ones occurring during gamete interaction and embryonic development. Moreover, ChE activities are responsible for other relevant biological events, including regulation of the balance between cell proliferation and cell death, as well as the modulation of cell adhesion and cell migration. Understanding the mechanisms of the regulation of these events can help us foresee the possible impact of neurotoxic substances on the environmental and human health.

Keywords: acetylcholinesterase, butyrylcholinesterase, cell communication, development, organophosphates, pre-nervous activity

\section{INTRODUCTION}

Neurotransmission systems are formed by sets of molecules which cooperate for the efficiency and control of the intercellular communication in both the nervous central (CNS) and peripheral (PNS) systems.

Since the 1970s, reports are available in the literature, suggesting that the highly organized synaptic neurotransmission may derive from evolution of ancestral pre-nervous (Buznikov et al., 1972) and non-nervous cell-to-cell communication systems, present since the prokaryotic cells (Stacy et al., 2011), and eukaryotic protists. In these last unicellular organisms, molecules belonging to the cholinergic, GABAergic and nitric oxide-based systems were found and related to the cell-to-cell communication driving the mating behavior (Delmonte Corrado et al., 1999, 2002). In paramecia, AChE activity was localized at the cell surface and along the ciliary rows (Delmonte Corrado et al., 1999). This activity was also found along the ciliated epithelia of stigmas of ascidian zooids, larval trochi, and generally at the basis of ciliated epithelia.

In addition, the expression and activity of acetylcholinesterase (AChE, E.C. 3.1.1.7) has been found during gametes interaction (Piomboni et al., 2001; Angelini et al., 2004, 2005; Falugi et al., 2008), embryonic development, in temporal and spatial windows related to differentiation and cell migration (Drews, 1975; Fluck et al., 1980; Falugi, 1993).

In addition, AChE can function as a regulator of inflamed tissues thanks to its role of support to apoptosis (Zhang et al., 2002; Zhu et al., 2008) which is the main objective of anti-tumor therapies.

The previously listed functions can be considered pre-nervous because they are based upon the catalytic effect of AChE enzyme on $\mathrm{ACh}$ and consequently on the ionic modulation of ACh receptors. On the contrary, the role played by AChE in cell adhesion (reported by Inkson et al., 2004; Bigbee and Sharma, 2004; for human and mammalian cultured cells) and in cell migration, including the elongation of axons toward their target (Giordano et al., 2007) is not exerted through acetylcholine cleavage. Instead, these effects are due to cellto cell and cell-matrix interactions, through the affinity of membrane-bound AChE molecules to laminin-1, identified previously as an in vitro AChE ligand and, to a lesser extent, to collagen IV and to AChE itself (Johnson and Moore, 2007).

Nevertheless, the possible role of the cholinergic system in non-nervous cell-to-cell communication is still controversial. In this review, we will follow the history of cholinergicrelated molecules in non-nervous and pre-nervous structures, and will outline the possible relationships between the exposure to cholinesterase inhibitors and developmental anomalies.

\section{THE CHOLINERGIC SIGNALING SYSTEM}

The cholinergic cell-to-cell communication is performed by a coordinated set of molecules, formed by the signal molecule, acetylcholine (ACh) and its muscarinic and nicotinic receptors, its biosynthetic enzyme, choline-acetyltransferase (ChAT, E.C. 2.3.1.6), the specific ACh lytic enzyme, acetylcholinesterase (AChE, E.C. 3.1.1.7), and other less specific choline esterases: butyryl-cholinesterase (BChE, E.C. 3.1.1.8) and propionyl-cholinesterase (PChE, E.C. 3.1.1.8), together called pseudocholinesterases (ChE). These are able to cleave ACh (acetylthiocholine iodide) at a minor rate compared to their specific substrates, butyrylthiocholine iodide (BTChI) and propionylthiocholine iodide (PTChI). In the past 20 years their role of implementing or substituting the tasks of AChE when its activity is impaired by inhibitors has been researched (Robitzki 
et al., 1998; Geyer et al., 2008; Pezzementi and Chatonnet, 2010). Actually, the pseudo-cholinesterase activities increase in case of stress due to the exposure to cholinomimetic drugs during chick development (Angelini et al., 1998; Aluigi et al., 2005) or to cholinesterase inhibitors in cultured cells possibly as a homeostatic response to AChE activity failure.

In most marine invertebrates, and/or in some tissues of marine invertebrates, PChE activity is preeminent compared to the others (see Figure 13). Actually, AChE and BChE are thought to be the result of a gene duplication event early in vertebrate evolution, soon after the appearance of gnatostomes (Massoulié et al., 1993; Pezzementi et al., 2011).

\section{ACETYLCHOLINESTERASE AS A MODULATOR OF THE CHOLINERGIC COMMUNICATION SYSTEM}

The enzyme AChE removes ACh from the receptors, in order to make them able to respond to the following impulses. AChE inhibition, such as the one caused by exposure to nerve weapons or to neurotoxic pesticides, would prevent ACh receptors rescue and cause enormous damages, blocking all the functions depending from ACh reception. The magnitude of the effect is due to the amount of blocked receptors, which depends on the body mass of the target organisms. In general, the impairing of AChE activity may generate in specific animal models the increase of central cholinergic tone, inducing the behavioral analogy of depression (Sklan et al., 2004). This implies a correlation between the correct functioning of AChE and human health, including neurodegenerative diseases.

\section{NON-NEUROMUSCULAR ROLES OF THE MOLECULES RELATED TO THE CHOLINERGIC SYSTEM}

In the first half of the last century, Youngstrom (1938) reported the presence of the enzyme activity in the embryos of three amphibian species long before the onset of the nervous system. In these cases, ChE activity increases since the 2-4 stage cells up to the beginning of tadpole motility. In Ambystoma punctatum, Sawyer (1943) observed the same behavior.

Whittaker et al. (1977) found cholinesterase since the first cleavage in the cells of the muscular genealogy of ascidian embryos. As the ascidian embryos develop according to the mosaic type, such localization has to be considered as a case of chemical differentiation preceding the structural one, rather than a pre-nervous activity, that generally is involved in instructive cell to-cell communication. On the contrary, the epithelial localization of AChE activity in the ascidian embryo and larva, reported by Minganti and Falugi (1980) should be considered an ancestral neuromuscular-like activity, because it is involved in the shrinkage of the tail epithelial cells during metamorphosis, and is enhanced by acetylcholine exposure (Coniglio et al., 1998).

A number of research groups found active ChE localized in extra-neuromuscular sites of different animal embryos, including invertebrate (Drews, 1975), and vertebrate embryos (Drews, 1975; Fluck et al., 1980; Minganti and Falugi, 1980; Minganti et al., 1981), and in developing buds of vegetal organisms (Raineri and Modenesi, 1986, 1988). They suggested that this AChE activity might be related to "embryonic" functions: cell migration (Drews, 1975) and cell-to-cell communication related to positional information exchange, such as the one between apical ectodermal ridge (AER) and mesenchyme during the limb development (Drews, 1975; Falugi and Raineri, 1985). In the limb bud, active AChE diffuses from the AER to the underlying mesenchyme, with focal points in the pre-cartilage cell clusters, and disappears in the core of early cartilage nodules (Figure 1).

\section{ChE ACTIVITY IN DEVELOPMENTAL EVENTS}

All the instructive signaling in developmental events is mediated by cell-to-cell communication: in particular, molecules related to neurotransmitter systems play a relevant role in modulating messages mediated by ion fluxes or ion intracellular changes. Buznikov and colleagues (Buznikov et al., 1972, 1996; Buznikov, 1980, 1990; Buznikov and Shmukler, 1981; Buznikov et al., 2001) detailed the history of classic neurotransmitter involvement (biogenic amines, acetylcholine, nitric oxide, and GABA) in early developmental events from fertilization and segmentation to organogenesis of highly specialized structures (Buznikov, 1990; Buznikov et al., 1996). They found evidence that developmental changes in this functional activity are involved from the stage of maturing oocytes through neuronal differentiation. This scheme reflects not only the spatial-temporal sequence of these changes, but also the genesis of neurotransmitter functions, from "protosynapses" represented by interacting gametes and cleaving embryos to the development of specialized synapses belonging to the neuromuscular system.

Professor Minganti's group (Minganti et al., 1975, 1981; Minganti and Falugi, 1980) advanced the hypothesis that the embryonic localization of ChE activities might be related to its role in the modulation of intracellular dynamics responsible for cell-to-cell communication. These assumptions were confirmed by experiments on a number of models, including chordates and high vertebrates (Minganti et al., 1981). The demonstration of these functions was achieved only years later using ChE inhibition bioassays, either with specific inhibitors such as BW284c51, iso-OMPA, and physostigmine, (Sigma, IT), or with organophosphate and carbamate anti-ChE compounds. In all the biological systems investigated, including human stem cells, AChE and $\mathrm{BChE}$ activities were found to perform different tasks. BChE is involved in the regulation of cell proliferation, while $\mathrm{AChE}$ is involved in cell differentiation (Sperling et al., 2008). This is characterized by decreased proliferation and increased cell death. ChE inhibitors also cause changes in intracellular calcium concentration and calcium-related membrane permeability as demonstrated by chlortetracycline (CTC) and merocyanine potentiometric dyes (Aluigi et al., 2010). Electrical events were always present in the cells and tissues characterized by the presence of AChE and/or ChE activities, and were always affected by either AChE inhibitors or cholinomimetic agents.

\section{THE SPATIAL-TEMPORAL WINDOWS}

The distribution of active ChE molecules occurs from fertilization, cleavages, gastrulation, etc., according to successive temporal windows, and in different expression fields, whenever and wherever cell-to-cell interaction takes place. The fields of expression of these molecules are more and more restricted as development proceeds, and in differentiated structures are only expressed in the "mature" neurotransmission sites. 

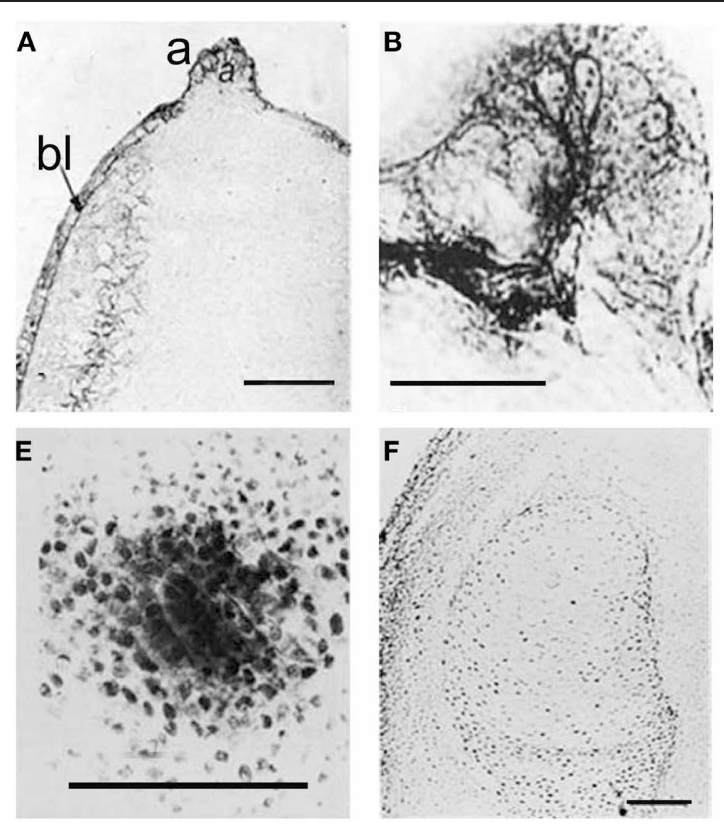

FIGURE 1 | Karnovsky and Roots 81964 reaction, showing AChE activity by a dark precipitation. (A) Forty-eight hours stage, longitudinal section, $15 \mu \mathrm{m}$ thick; (B) AER, same stage; (C) Seventy-two hours stage, showing that from the AER and dorsal ectoderm AChE activity is diffused to focal point where the pre-cartilage cells begin to differentiate (D);

\section{Sperm-egg interaction}

In gametes, the presence and localization of AChE activity was investigated by several researchers. In sperms a number of cholinergic molecules and receptors were localized in sites which suggest their involvement in the regulation of propulsion and fertilizing ability. Nelson (Nelson, 1964, 1978; Nelson et al., 1970) related the localization in the flagellum to the regulation of sperm motility. In fact, sperms present ChE activity (AChE) at the surface of the acrosome, in flagella (Chakraborty and Nelson, 1976; Cariello et al., 1986) and in the neck region. In addition, a high number of reports showing bioassays with AChE and ChE inhibitors shed light on the relevant function of ChEs in sperm swimming and fertilizing ability (Perry, 2008; Okamura et al., 2009), including epidemiological studies in humans professionally exposed to pesticides (Yucra et al., 2008).

Concerning ovogenesis, AChE activity has been localized in ovogonia at different maturation stages in several animal species: in sea urchins (Figure 2A), ascidians (Cangialosi et al., 2006), copepods etc. The AChE protein was localized around the nuclei in early maturation stages and close to the oocyte surface (Figure 2A). In the same sites AChE activity was localized by electron microscopy in the perinuclear cistern, in the Golgi vesicles and, at maturation, in vesicles close to the surface, (Figure 2B) including the cortical granules (Falugi et al., 1993). This active AChE is important as it cooperates to prevent polyspermy. In fact, activated sperms release the acrosomal granule (Figure 4A) in order to pass through the egg envelope, and expose the postacrosomal membrane, containing ChAT (Figure 4B, Angelini et al., 2004). This causes the synthesis of ACh that binds to the nicotinic receptors in the egg membrane (characterized by
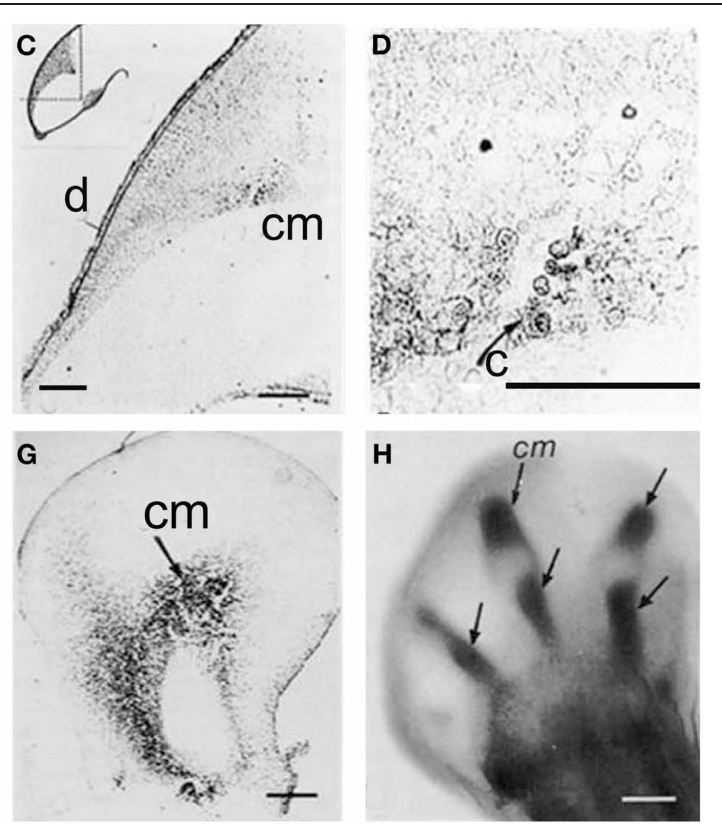

(E) Pre-cartilage mesenchyme condensation; (F) Five days stage, no AChE activity is present inside the cartilage core. $(\mathbf{G}, \mathbf{H}) \mathbf{B C h E}$ activity in pre-cartilage buds. a, AER; bl, basal layer; $C$, cartilage; cm, cartilage matrix; d, dorsal; e, ectoderm; m, mesenchyme [from Falugi and Raineri (1985)].

Ivonnet and Chambers, 1997). The small $\mathrm{Na}^{+}$entrance caused by the excitation of nicotinic AChR produces a small membrane depolarization (described by Epel, 1980), that causes membrane permissivity to the sperm-egg fusion. If it is maintained by exposure to eserine or to nicotine (Baker and Presley, 1971; Angelini et al., 2004), such low depolarization allows polyspermy.

In this moment AChE, that has been synthesized in great amount and stored inside the cortical granules and other membranous vesicles (Figures $\mathbf{3 A - C}$ ), is released into the perivitelline space (Figure 4C), where it cooperates with the fast block to polyspermy, by immediately removing ACh from its receptors localized in the oolemma. After the release of the cortical granules, AChE activity is present for a short time at the membrane of the fertilization cone (Figures 3D-F).

\section{Early embryonic development and differentiative events}

In differentiating stem cells, such as NT2 and pre-adipocytes (Aluigi et al., 2010, 2009), the presence of AChE molecules around the nuclei and in the cytoplasm was shown since the stage 0 by immunohistochemical methods and was confirmed by the presence of specific mRNA. The ChE activity was differently distributed, showing that part of the $\mathrm{AChE}$ molecules present in the cells are not active and other ChE active molecules nonimmunoreactive to the AChE specific antibody are present in the cytoplasm (Figures 5E,F).

During segmentation, ChE activity is localized at the surface of blastomeres facing each-other (Figures 5A,B). This also appears to be true for the NT2 cultured cells in the proliferative stage (Figures 5C,D). At these early stages (cleavage divisions) Buznikov and Shmukler (1978) and Shmukler (1981, 1993) 


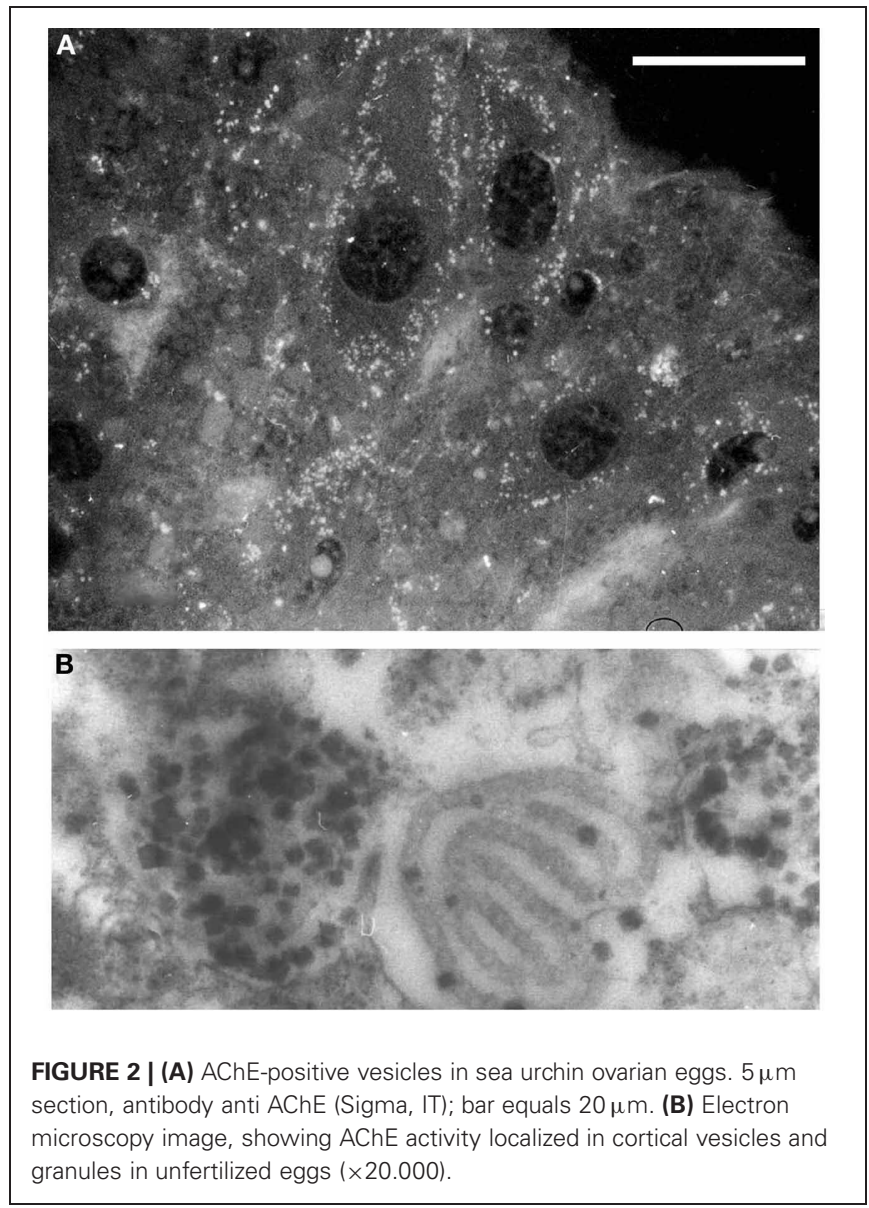

reported the presence of a serotoninergic cell-to-cell dialogue between blastomeres and put it in correlation with a pre-nervous membrane signal reception. This suggests a cooperation between prenervous transmitter mechanisms similar to nervous ones in establishing a precocious positional information. Shmukler et al. (1981) also reported a time-dependent passage of positional information: if separated soon after cleavage, the majority of blastomeres remain totipotential, if separated little bit later (about 10 min after blastomere post-division adhesion), the blastomeres further develop with partial cleavage pattern.

A wide expression of acetylcholinesterase is found during gastrulation of invertebrate and vertebrate embryos except crustaceans, round worms and insects, probably because the mosaic development of these organisms does not need informational inputs. In vertebrates the Hensen's node and the consequent chord-mesoderm present intense AChE activity since their first organization (Figure 6A).

The successive AChE localization is found in the somites and in the rhombomeres, and is a precursor of the real neural function of the enzyme. From the whole bodies of metameric somites, AChE activity is progressively restricted to the myotomes. In the dorsal chord AChE remains active for a long time, extending to the neural floor plate long after the neural tube closure.

At this stage, an intense exchange of inductive messages is still present between the dorsal chord and the floor plate. These

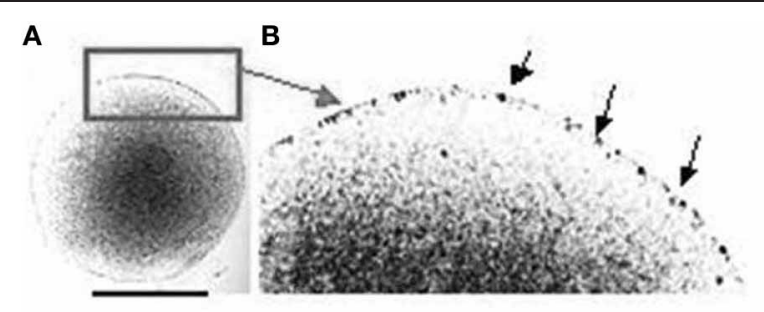

C

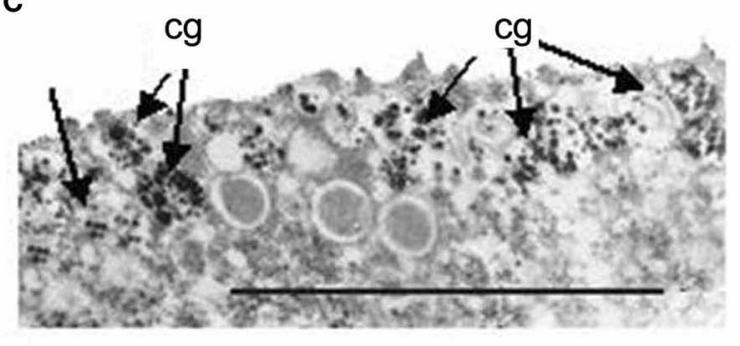

D

E

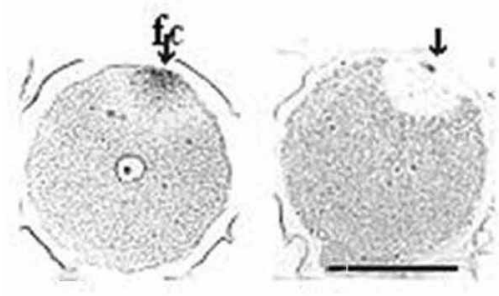

$\mathbf{F}$

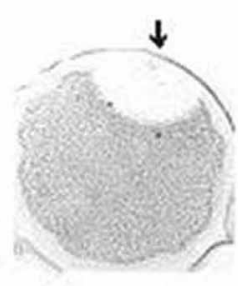

FIGURE 3 | (A) AChE reaction is localized in membranous granules at the periphery of the egg cell. (B) Higher magnification of the cortical layer, corresponding to the rectangular area in $\mathbf{A}$. The arrows point to some of the positive granules. (C) TEM image of the same granules. The AChE reaction (dark staining) is reduced to the surface of the fertilization cone after fertilization. (D,E,F) The arrows show the point of sperm entry. Bars equal $50 \mu \mathrm{m}$. f, fertilization cone.

messages have a crucial role in building the neural tube architecture, as demonstrated by Placzek et al. (1993) by transplantation experiments. The localization of AChE activity in these interacting structures is shown in Figures 6B,C. During organogenesis the enzyme activity is localized in the head, heart, and limbs and, later, in the feather buds of the dorsal skin (Figure 7).

\section{Cell migration}

Drews (1975) first reported the presence of AChE activity in migrating cells of sea urchin, amphibian, and chick embryos during the gastrulation events. The same localization was reported by (Fluck et al., 1980; Fluck and Shih, 1981) in Oryzias latipes mesoderm cell cultures. After these discoveries, the presence of AChE activity is considered as a good marker of migrating neural crest cells (Le Douarin, 1986) and of poly ingressing epiblast cells during gastrulation (Weinberger et al., 1984). The exposure to ChE inhibitors, such as eserine, was able to impair the movement of these structures, affecting skeletal rods elongation in sea urchin (Ohta et al., 2009) and causing the formation of cardia bifida in vertebrate embryos (Figure 8).

The functional mechanism of AChE in cell movement can be explained by the fact that AChE contains affinity sites to 


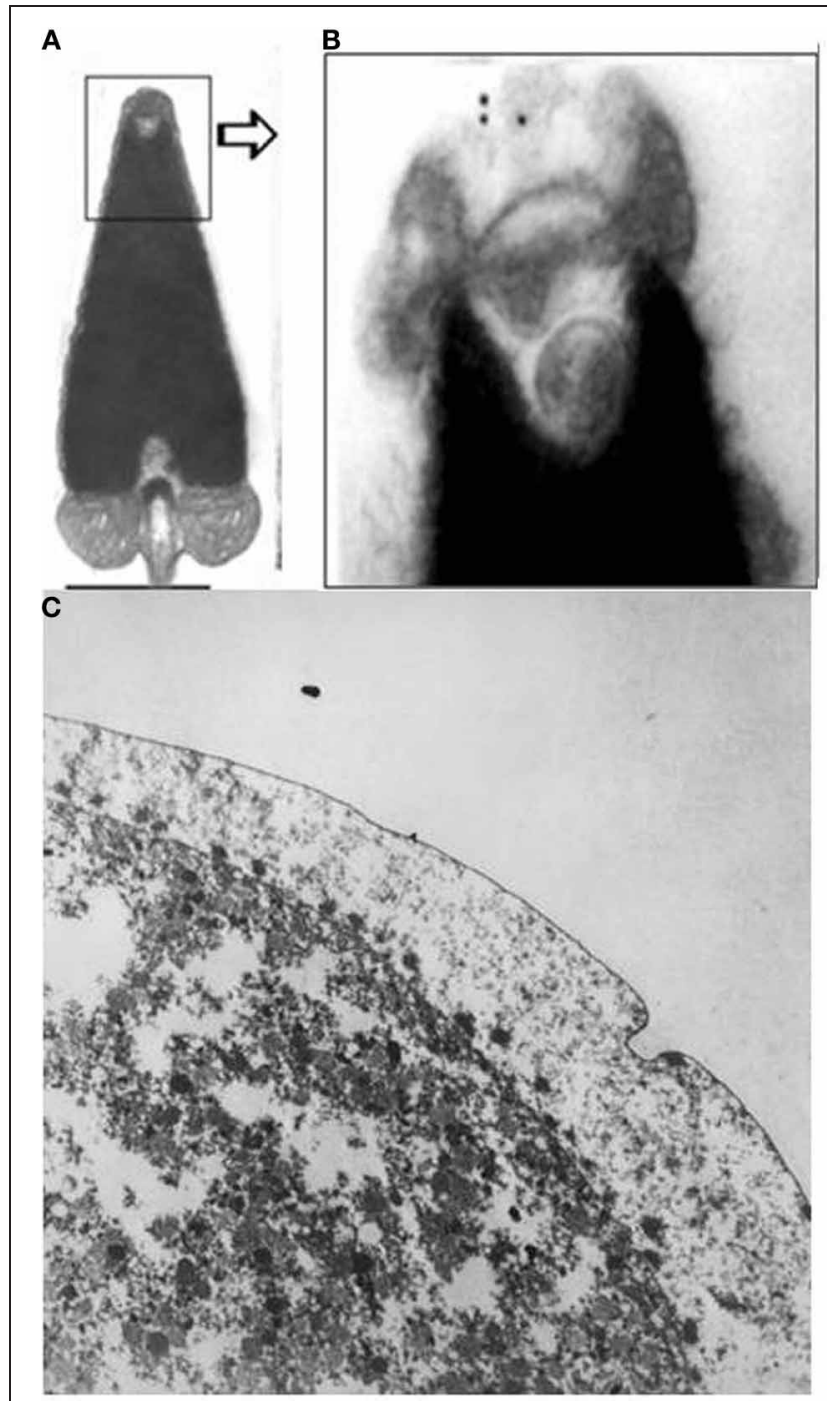

FIGURE 4 | (A,B) ChAT activity in the sperm acrosome (immunogold), electron microscopy images (Angelini et al., 2004; original images (A) bar $=$ $0.5 \mu \mathrm{m}$; (B) $\times 20,000$ ): (C) The arrows show some of the AChE-positive cortical granules exocytosized into the perivitelline space at fertilization $(\times 20,000) . \mathrm{OsO}_{4}$ was not used for fixation, in order to maintain the activity of AChE.

cell membrane or to matrix components, such as laminin and fibronectin (Bigbee and Sharma, 2004; Anderson et al., 2008). ChE molecules might directly interact with fibronectin, that is localized (Figure 9B) in the migration pathways during morphogenetic movements of both invertebrate and vertebrate embryos. The link between AChE (Figure 9A) and matrix components in these structures might be exerted through association with structural proteins, such as ColQ or PRiMA (described by Massoulié et al., 2008; Liang et al., 2009).

\section{CELLULAR EVENTS PRESENTING PRE-NERVOUS AChE ACTIVITY Inflammation and balance between apoptosis/cell proliferation}

Recently, inflamed cells and tissues were found to present a greater amount of ACh, (Wessler and Kirkpatrick, 2008), accompanied by

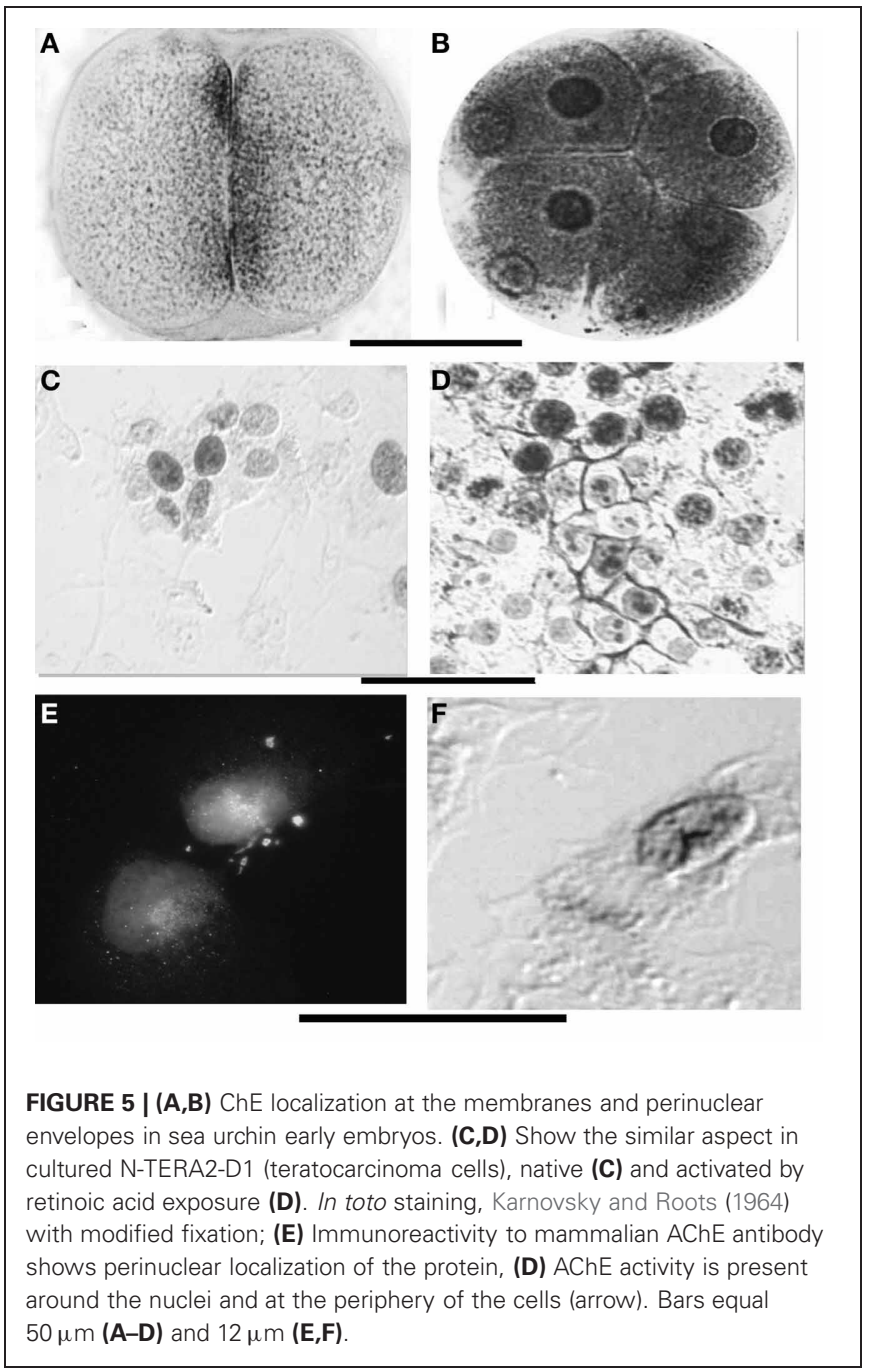

AChE expression (de Oliveira et al., 2012) and activity, compared to the healthy ones. A similar increase of AChE activity was found in wound healing tissues (Falugi et al., 1994). The ACh activity enhancement is known to trigger cell proliferation and block apoptosis, by the activation of nicotinic and muscarinic receptors (Thunnissen, 2009). The homeostatic increase of AChE, on the contrary, was demonstrated to increase apoptosis (Zhang et al., 2002; Mor et al., 2008b). For this reason, AChE activity seems to be a check point between proliferation (and possibly cancer promotion) and apotosis in inflamed tissues.

In cultured cells, cDNA microarray studies showed that the most statistically significant pathways affected by AChE inhibition were related to cellular death and cell proliferation (Catalano, 2007). Aluigi et al. (2010) supplied evidence that AChE inhibition may affect the balance between cell differentiation and proliferation of NTera2-D1 (NT2) cells in a dose-dependent way, from the early stages of differentiation, both in control and in retinoic acid exposed cells. NT2 cells showed a time-dependent increase of cell death, caused by exposure to AChE inhibitors, showing a number of features characteristic of apoptosis, including membrane and mitochondrial potential changes and caspase 

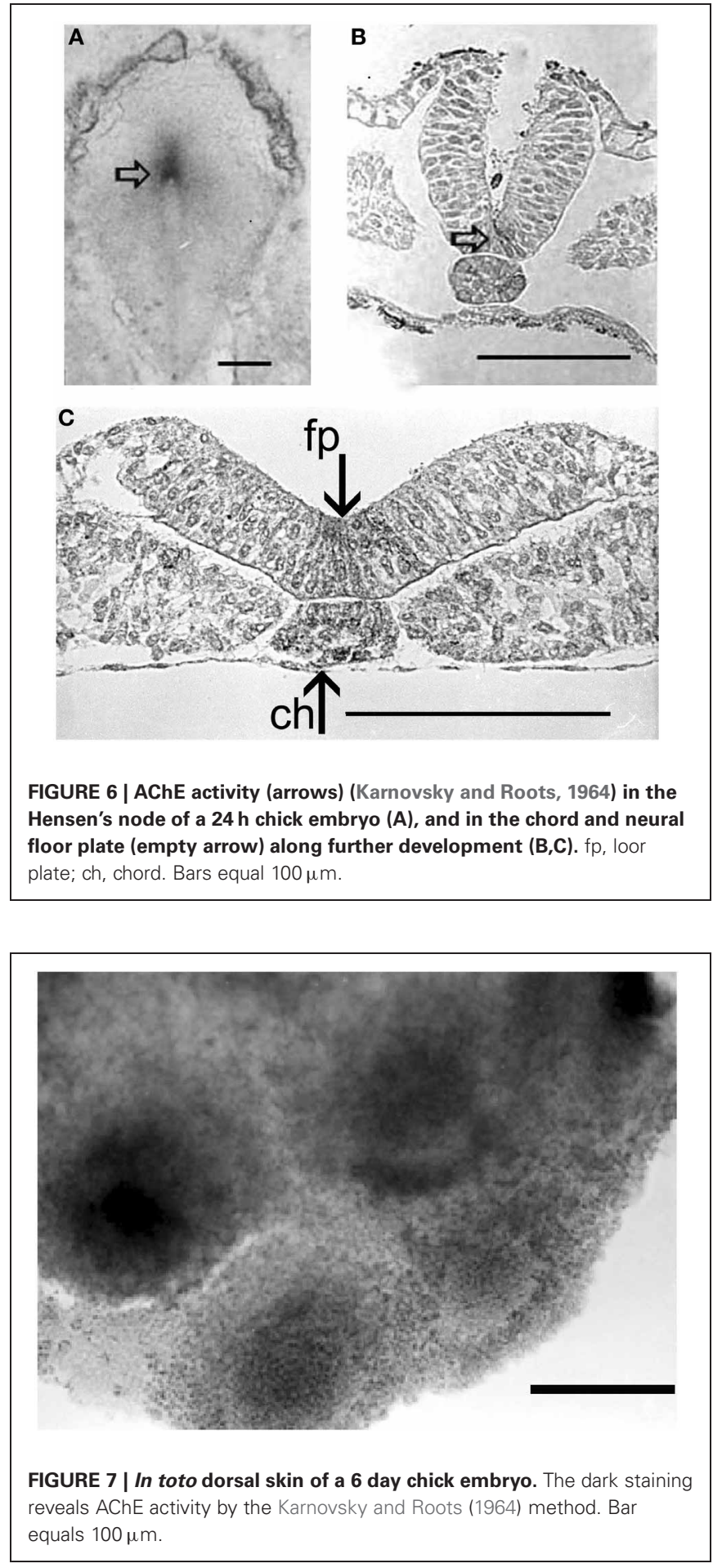

cascade activation. Since the NT2 cells possess acetylcholine receptors, the regulatory pathway on apoptosis may be exerted by AChE through the modulation of ACh present at the receptorial sites. In this case, the role of AChE should be considered as a pre-nervous, or even nervous activity, as it is related to the cleavage of $\mathrm{ACh}$, and to the consequent effect on nicotinic receptors.
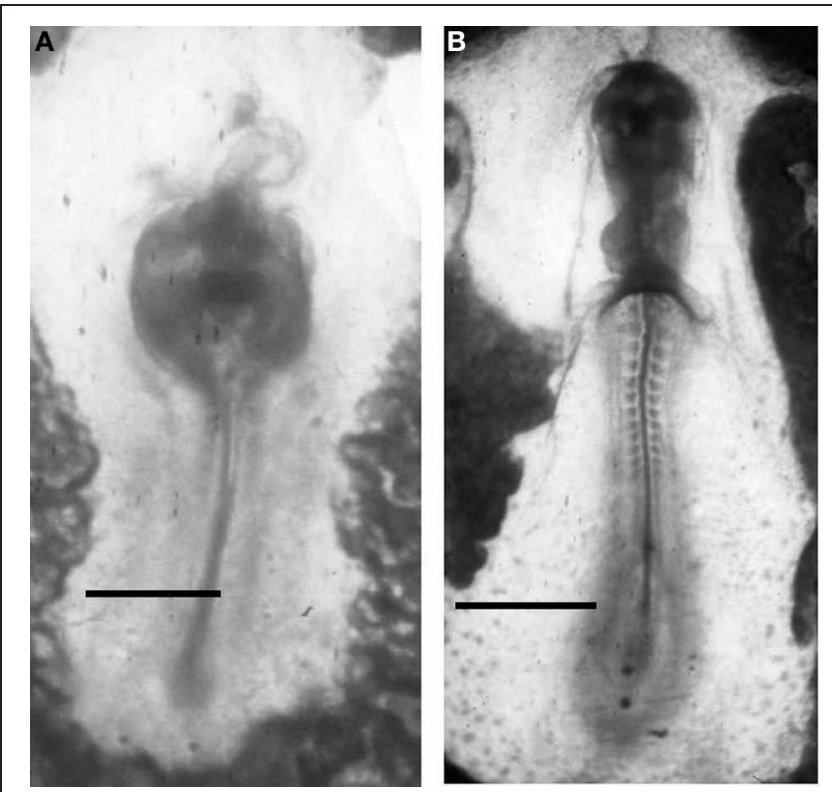

FIGURE 8 | ChE inhibition in $48 \mathrm{~h}$ chick embryos, exposed to $10^{-5} \mathrm{M}$ diazinon prevents anterior closure of the heart (the head is not developed) (A). Control at the same incubation stage (B). Bars equal $200 \mu \mathrm{m}$.

\section{CHOLINESTERASE ACTIVITY INHIBITION}

Most of the information about the functions of $\mathrm{ChE}$ molecules in development has been achieved through bioassays carried out using anti-ChE molecules, such as BW 284c51, physostigmine (eserine), tetraisopropyl pyrophosphoramide (Iso-OMPA), etc. In addition, a huge amount of information has been obtained from exposure to organophosphate (OP) and carbamate (CB) insecticides. These experiments were performed on the basis of applied research, with the aim to understand their impact on environmental and human health. While BW284c51 and isoOMPA are inhibitors discriminating between $\mathrm{AChE}$ and $\mathrm{BChE}$, the neurotoxic pesticides are less specific.

$\mathrm{OP}$ is the general name for the esters of phosphoric acid. These are the basis of a number of pesticides and insecticides used worldwide and poured into the environment in the amount of thousands tons every season. The OP compounds were actively studied during the Second World War as nerve agents to be used as weapons, and after the ban of DDT and other chlorine derivatives were widely marketed as neurotoxic insecticides (see Karczmar, 1970, for a thorough review).

These compounds and their formulate derivatives are used for a wide range of aims: from insect to small vertebrate pest control, at concentrations proportional to the body mass of the target organisms.

The OPs can affect the activity of all the ChE molecules, including true $\mathrm{AChE}$ and pseudocholinesterases, but not their expression, as it is demonstrated in Figure 10.

In blood the effects of such compounds may last a long time, because the AChE activity may be inhibited up to several months, as it was demonstrated in the case report (Romero et al., 1989) 


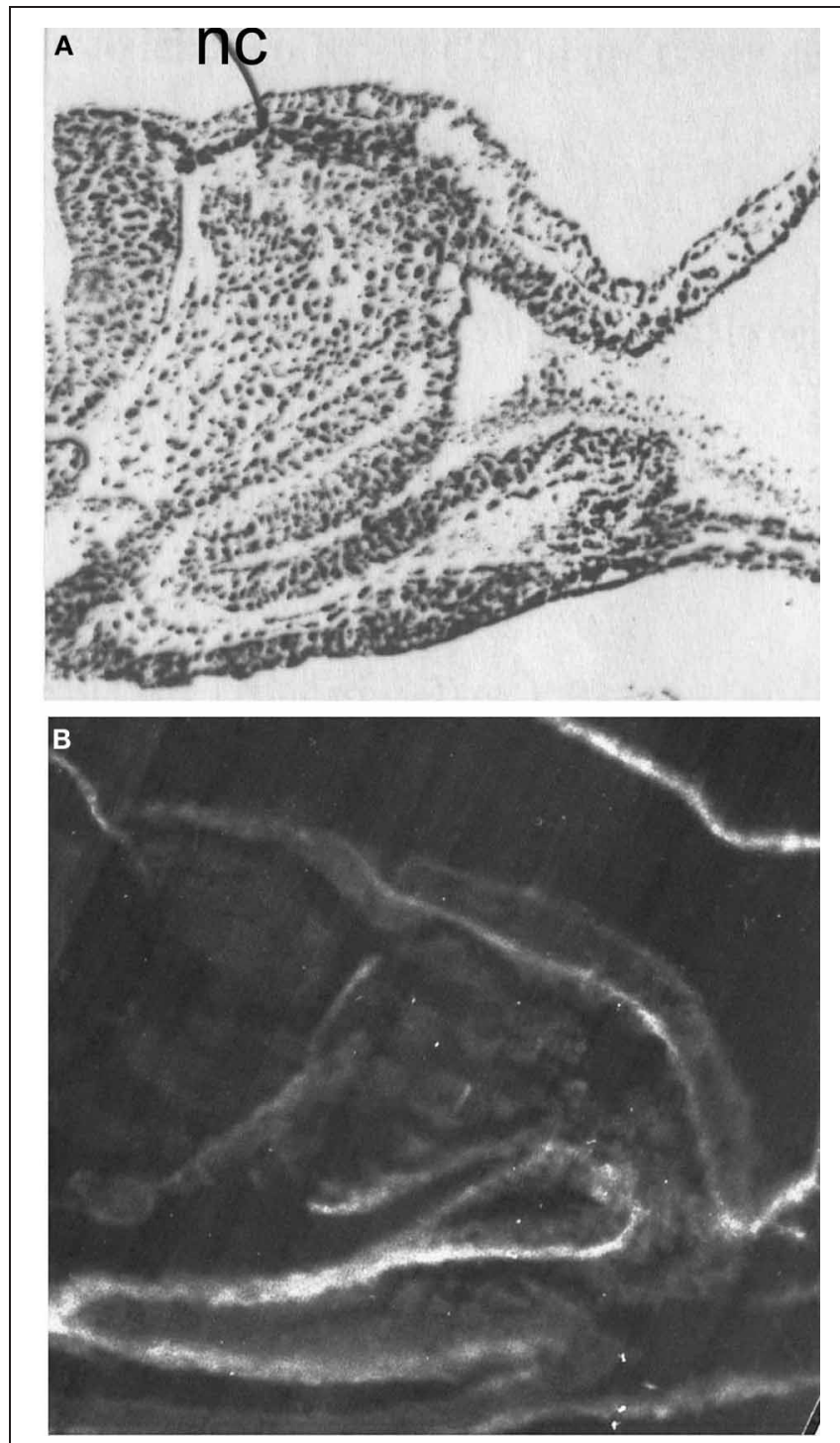

FIGURE 9 | Distribution of AChE activity (A) and fibronectin-like molecules (B). AChE activity is revealed by dark staining, (Karnovsky and Roots, 1964); Fibronectin is revealed by immunofluorescent reaction. Resin sections, $5 \mu \mathrm{m}$; nc, neural crest. Bar equals $100 \mu \mathrm{m}$.

resulted by monitoring a group of exposed farmers. In that case, pesticides were also able to pass through the placental barrier of a pregnant woman, causing embryonic anomalies.

The same aspect is revealed in human NT2 cells exposed to $10^{-4} \mathrm{M}$ pesticides (Figure 11):

Moreover, the toxic potential varies considerably among the different pesticides, as demonstrated by Zoltan Rakonczay (SENS-PESTI report, 2006), and their effect is different among different organisms and also among different tissues. Rakonczay and Papp (2001) found that after an acute ( $4 \mathrm{~h}$ ) treatment with an irreversible cholinesterase OP inhibitor, metrifonate, the activities of both AChE and BChE were inhibited in the rat brain cortex and hippocampus, while no significant changes were present in the other parts of the brain, such as olfactory bulb, or in the choline acetyltransferase activity in all three brain areas.

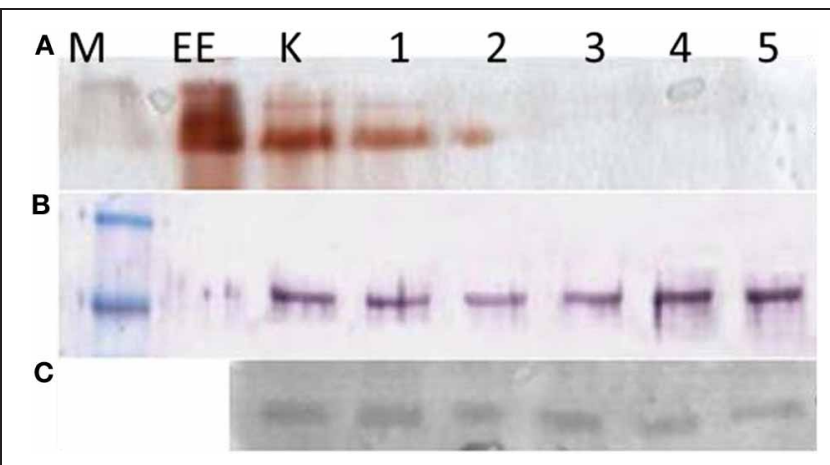

FIGURE 10 | Blood lymphocytes and monocytes isolated from buffycoats of different donors. (A) Electrophoretic revelation of ChE activity, by the Karnovsky and Roots (1964) method; (B) AChE immunoreactive molecules $(M=82 \mathrm{kDa})$. These are present in all the lanes, but inactive in the 3, 4, 5 lanes. (C) CDF/LIF ( $M=\sim 27-30 \mathrm{kDa})$, the cholinergic differentiation factor expression also seems scarcely affected. $\mathrm{M}$, molecular mass; EE, 15 units of electric eel AChE; K, control; 1, BW $10^{-4} \mathrm{M}$; 2 , iso-Ompa $10^{-4} \mathrm{M}$; 3 , chlorpyriphos $10^{-5} \mathrm{M}$; 4 , chlorpyrifos oxon $10^{-5} \mathrm{M} ; 5$, carbaryl $10^{-5} \mathrm{M}$.

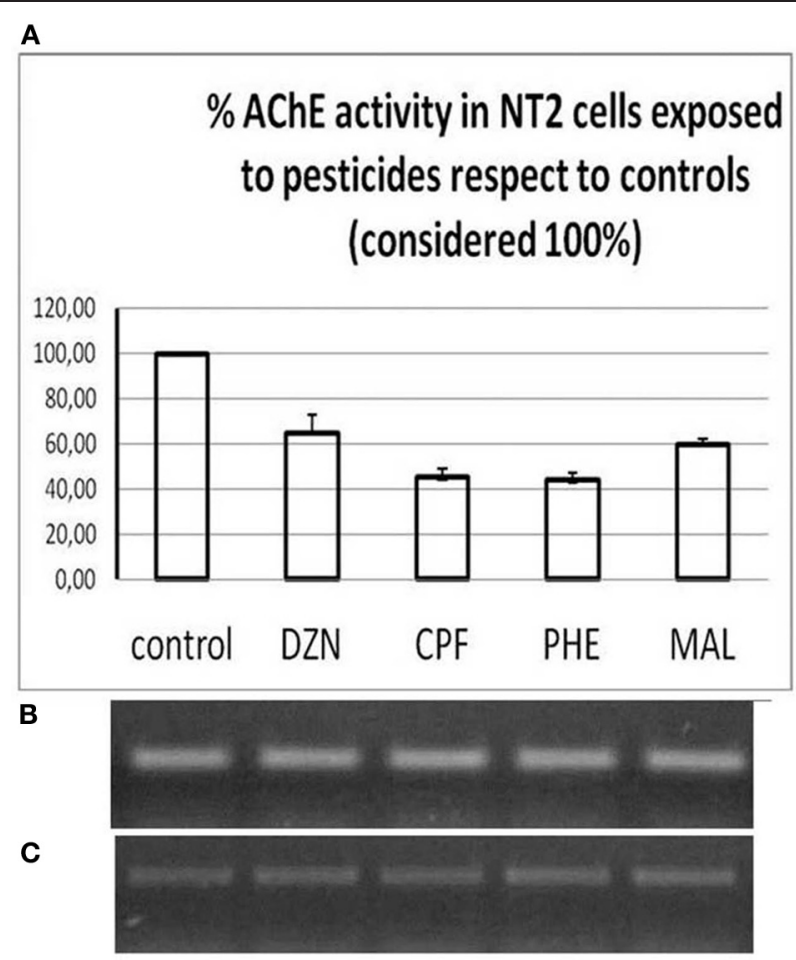

FIGURE 11 | NT2 cells exposed to $\mathbf{1 0}^{-\mathbf{5}} \mathbf{M}$ inhibitors. (A) Changes in AChE activity; (B) Corresponding AChE mRNA (538 bp) amounts; (C) Actin expression (259 bp). DZN, diazinon; CPF, chlorpyrifos; PHE, phenthion; MAL, malathion.

\section{DEVELOPMENTAL OP TOXICITY TARGETS}

Reproductive (Nelson, 1990) and developmental facts (Chanda and Pope, 1996; Aluigi et al., 2005, 2008, 2010) were demonstrated by maternal, embryonic or differentiating cells exposure to $\mathrm{OP}$ pesticides. The effects were dose-dependent as shown 
by in vitro fertilization and morulae formation experiments (Ducolomb et al., 2009).

The developmental anomalies occurring after exposure to cholinergic drugs generally regard tissues and organs where, in normal conditions, AChE activity is mainly localized. Thus, the main effects of exposure to AChE activity inhibitors are related to three classes of developmental events:

1. During gamete maturation, activation and interaction (Angelini et al., 2004, 2005).

2. During the early development of invertebrate and vertebrate embryos. In this case cholinergic molecules are located mainly in moving cells and tissues engaged in relevant morphogenetic events, such as gastrulation, and are often co-distributed with special extra-cellular matrix molecules such as fibronectin (Aluigi et al., 2005) and laminin (Johnson et al., 2008).

3. During inductive communications between mesenchyme and other tissues, such as the limb bud development (Falugi and Raineri, 1985), eye and heart formation (Aluigi et al., 2005), neural floorplate induction, etc. By use of different animal models, at different developmental stages, it was demonstrated that neurotoxic insecticides (diazinon, carbaryl, pyrimicarb, and their commercial formulates), may affect calcium dynamics since fertilization events (Pesando et al., 2003) and during embryo and larval development.

By diazinon exposure of sea urchin early embryos, evidence was provided that cytoplasmic dynamics were perturbed in a dosedependent way, thus affecting the endonuclear delivery of the OTX2 protein. This may be due to altered calcium dynamics, which in turn alter cytoskeleton dynamics: the asters, in fact, appeared strongly positive to the OTX2 immunoreaction (Aluigi et al., 2008). Pesando et al. (2003) also showed that, during sea urchin development, the treatment with organophosphates decreased the rate of early mitotic cycles and affected nuclear and cytoskeleton status as well as DNA synthesis.

\section{EFFECT OF ChE INHIBITORS ON GAMETOGENESIS AND FERTILIZATION}

Most of the information about the effects of OPs on reproductive success has been obtained in countries where the socioeconomic engine is based on agriculture (Contreras et al., 2006). Exposure to these inhibitors caused a significant decrease of sperm count and increase in teratozoospermia (Bustos-Obregón and González-Hormazabal, 2003). Only a few reports are available in the literature about the effect of cholinesterase activity inhibition on gametogenesis, but recently neurotoxic pesticides have been recognized as emerging endocrine disrupters (Canesi et al., 2011). In porcine in vitro models of ovogenesis and fertilization, exposure to two organophosphotionate compounds (diazinon and malathion) caused greater effects than classical endocrine disrupters, such as atrazine and fenoxa-propethyl. The insecticides affected viability and, by a major degree, maturation by blocking the oocytes at the germinal vesicle stage (Casas et al., 2010).

In this case, the activity of the OP compounds seems to be due to the lipofilicity of the molecules that are able to pass through the cell membrane and behave at the same way as steroid
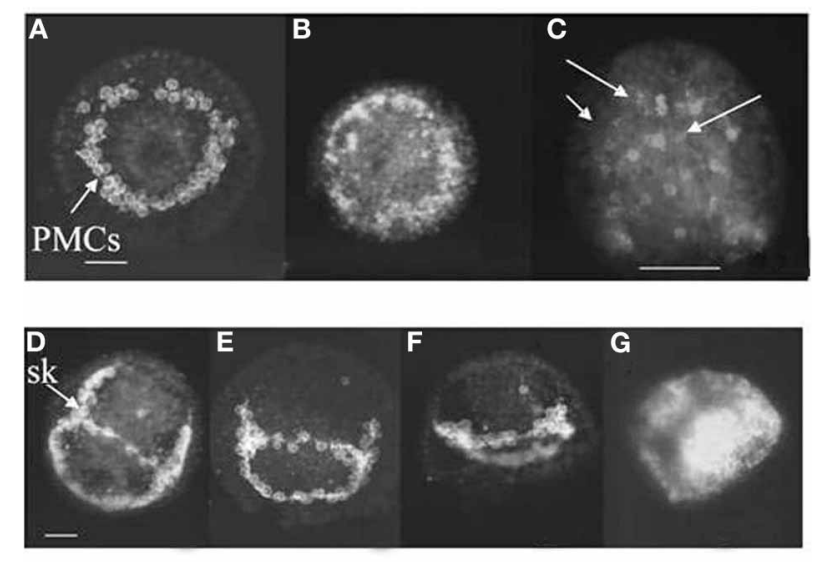

$\mathbf{H}$

I
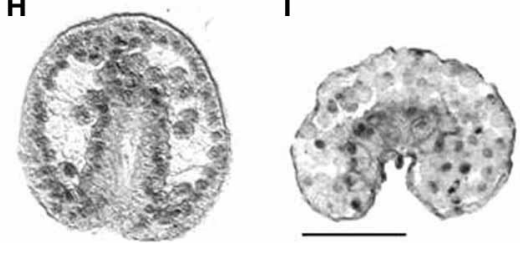

FIGURE 12 | Sea urchin gastrulae exposed to diazinon during fertilization. Arrows point to PMCs. Upper rows: WGA affinity sites for primary mesenchime cells (PMC). (B,C) $10^{-4} \mathrm{M}$ diazinon; (E-G) $10^{-5} \mathrm{M}$, $10^{-4} ; 10^{-3} \mathrm{M}$ diazinon. (A,D) controls (Pesando et al., 2003). (H,I) OTX2 immunoreactivity in control $\mathbf{( H )}$ and exposed to $10^{-5} \mathrm{M}$ diazinon (I) larva (Aluigi et al., 2008). Sk, skeletal rod; bar $=10 \mu \mathrm{m} ;(\mathbf{C}, \mathbf{H}, \mathbf{I})$ bar $=50 \mu \mathrm{m}$.

hormones, thus addressing the same mechanisms of the classical endocrine disrupters. In addition, OP-induced stress evoked a mutated AChE form, the AChE-R that was demonstrated to be involved in sperm motility regulation (Mor et al., 2008a,b).

In sea urchin gastrulation, the exposure to OPs, CBs, and AChE inhibitors, such as BW284c51, slowed movement of the primary mesenchyme cells (PMCs, Figures 12A-G) causing the formation of apparently diblastic gastrulae (Aluigi et al., 2008; Figure 12I), more flattened as compared to control embryos (Figure 12H). These experiments showed that AChE is also involved in the control of regulatory proteins delivery into the nucleus, thus affecting key genes expression (such as OTX2), which is linked to the cytoskeletal dynamics (in turn regulated by calcium).

\section{Body patterning}

Anti-cholinesterase insecticides, widely used for agricultural purposes, mainly affect the cholinergic system by inhibition of cholinesterase activities and muscarinic receptors (Hayes and Laws, 1991; Mineau, 1991). These have been thoroughly studied by a number of researchers using the early development of the Mediterranean sea urchin Paracentrotus lividus as a model (Pesando et al., 2003). For the morphological effects on fertilization and first cleavages, the effective concentration of the organophosphate diazinon was found to be $10^{-4} \mathrm{M}$, while for further stages concentrations between $10^{-5} \mathrm{M}$ and $10^{-7} \mathrm{M}$ were effective. The $10^{-3} \mathrm{M}$ concentration arrested development. Moreover, during embryonic development, the treatment with 
organophosphates slowed the rate of early mitotic cycles, affected nuclear and cytoskeleton status as well as DNA synthesis (Pesando et al., 2003).

These results paved the way to new hypotheses: Buznikov et al. (2007) affirmed that sea urchins and generally lower organisms show promise for the screening of neurotoxicants that might target mammalian brain development, based on the use of neurotransmitters as embryonic growth regulatory signals. The Authors compared the effects of the organophosphate insecticide, chlorpyrifos, in sea urchin embryos with those of the monoamine depleter, reserpine. They also stated the fact that chlorpyrifos works simultaneously through actions on acetylcholine, monoamines and other neurotransmitter pathways. Membrane permeable cholinomimetic substances and cannabinoids prevented chlorpyrifos- or reserpine-induced teratogenesis. In this way, the Authors envisaged the possibility to propose both a screening procedure for mammalian neuro teratogenesis and therapeutic approaches to prevent teratogenesis mediated by exposure to chemicals.

\section{Electromagnetic fields}

Different experiments showed that electromagnetic fields can affect the speed of cell proliferation, enhancing development of sea urchin early embryos and larvae (Falugi et al., 1987) as well as alter the symmetry of blastomeres (Ravera et al., 2006). These last authors found that exposure of fertilized eggs of the sea urchin Paracentrotus lividus to an electromagnetic field of $75-\mathrm{Hz}$ frequency and low amplitudes (from 0.75 to $2.20 \mathrm{mT}$ of magnetic component) caused asynchronous development since the first cell cycle and anomalous embryos showing irregular separation of chromatids during the mitotic events. At the same time, this exposure was also able to impair AChE activity in unicellular organisms (Amaroli et al., 2005) and in particular the one of the PRIMA form, which is linked to the cell membranes. The enzymatic activity was assayed by Ravera et al. (2006) in sea urchin embryo homogenates and decreased by $48 \%$ when the homogenates were exposed to the same pulsed field, with a threshold of $0.75 \pm 0.01 \mathrm{mT}$. The same field threshold was able to cause the formation of anomalous embryos of $P$. lividus. Blockers of ACh receptors are able to antagonize those effects. The relationships between the effects of EM fields and the cholinergic system seems to be reliable, but it is still rather puzzling, because also other membrane-bound enzymes, such as phosphatases, are strongly impaired by this kind of electromagnetic fields.

\section{Non-cholinergic stressors}

Damage from a number of environmental stressors, causing stress-related electrical potential in cells, was followed by dosedependent changes in AChE activity. The example reported below (Figure 13) shows the effect of $10^{-6} \mathrm{~g} / \mathrm{L}$ nanoparticles on the coelomocytes of sea urchins exposed for 5 days. PChE was the most affected activity, because in sea urchin coelomocytes it is the preeminent one.

\section{MOLECULAR FORMS OF THE NON-NEUROMUSCULAR ChES}

In the non-neuromuscular fragile cells, such as protists, very early embryos and cnidarians, ChE activity was completely inhibited

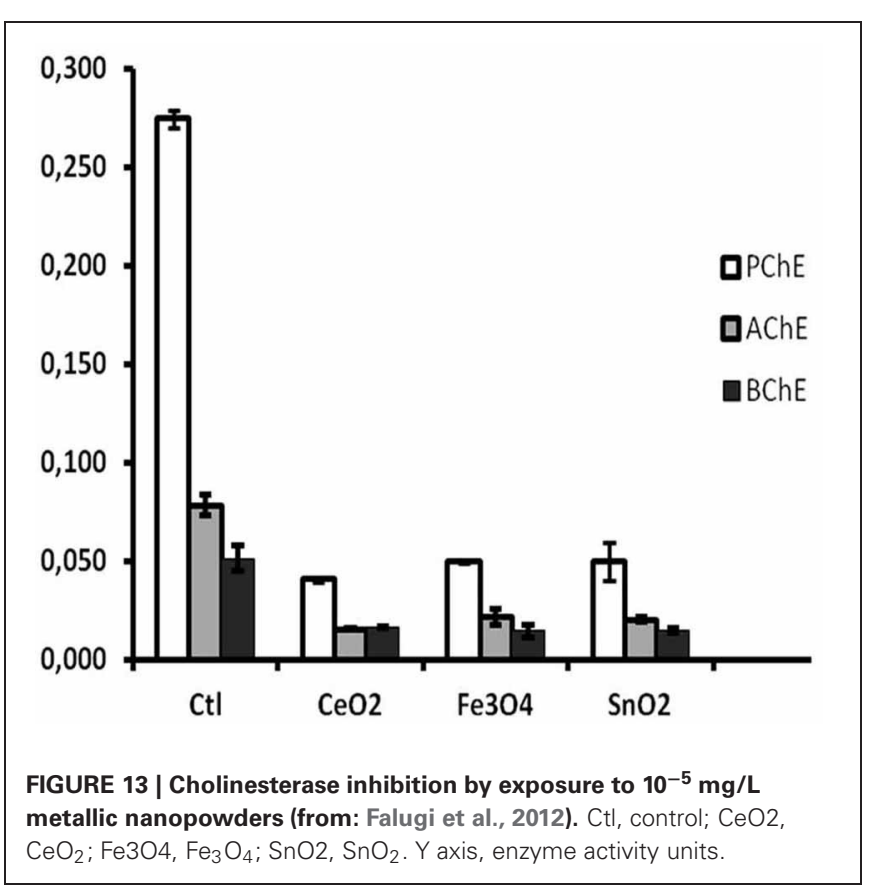

by the routinely used fixation by alcohol 80 , suggested by the protocols running during the 1970s. Following the observation that paraformaldehyde vapors were able to fix protozoans and ascidian embryos preserving the enzyme activity, a modified "gentle" fixation procedure was suggested for the histochemical detection of the "embryonic" AChE activity (Minganti et al., 1981). Using this method, the pre-nervous AChE activity was widely localized in the presumptive differentiating areas, becoming more and more restricted to the differentiated neuromuscular sites, where the activity was strong and resistant to usual fixatives. Minganti and Falugi (1980) advanced the hypothesis that these "embryonic" ChE enzymes were represented by smaller and less active forms than the mature ones, present at synapses. The hypothesis of Minganti et al. (1981) was that the slow cell-to-cell communications taking place during development do not need the high speed and consequently the high differentiation needed at synapses.

ChEs are present with multiple isoforms formed by monomer and olygomer subunits displaying catalytic activity, with relatively low molecular weight. These are assembled forming more heavy complex polymeres, with either globular or asymmetrical shapes (Massoulié et al., 1993). The most specialized polymeres of $\mathrm{AChE}$ are present at synapses, where they exert their mature function, characterized by speed and efficiency. The catalytic activity of the molecular forms seems to depend on the size: according to the parameter of thermolability used by Edwards and Brimijoin (1983) the most thermolabile molecular form in a number of examined tissues was represented by the monomeric $4 \mathrm{~S}$ enzyme.

More recently, the group of scientists lead by Hermona Soreq (Mor et al., 2008a,b) reported a further complexity in the possible AChE molecular forms, comprising a mutated type of AChE, the AChE-R, which is expressed in organisms and tissues exposed to different stress kinds. In addition, the scientists 
underline the role of microRNAs in post-transcriptional selective splicing of the molecules, which pave the way to understanding the multifunctional role of $\mathrm{AChE}$ and BChE both in development and in stress scenarios (Shaked et al., 2009; Meerson et al., 2010; Hanin and Soreq, 2011; Barbash and Soreq, 2012), including inflammation and apoptosis. These findings are very interesting, because alternative splicing is a relevant tool for the control of early development, allowing the creation of stage-dependent

\section{REFERENCES}

Aluigi, A. G., Coradeghini, R., Guida, C., Scanarotti, C., Bassi, A. M., Falugi, C., Santi, P., and Raposio, E. (2009). Pre-adipocytes commitment to neurogenesis 1 , preliminary localization of cholinergic molecules. Cell Biol. Int. 33, 594-601.

Aluigi, M. G., Angelini, C., Corte, G., and Falugi, C. (2008). The sea urchin, Paracentrotus lividus, embryo as a "bioethical" model for neurodevelopmental toxicity testing: effects of diazinon on the intracellular distribution of OTX2like proteins. Cell Biol. Toxicol. 24, 587-601.

Aluigi, M. G., Angelini, C., Falugi, C., Fossa, R., Genever, P., Gallus, L., Layer, P. G., Prestipino, G., Rakonczay, Z., Sgro, M., Thielecke, H., and Trombino, S. (2005). Interaction between organophosphate compounds and cholinergic functions during development. Chem. Biol. Interact. 157-158, 305-316.

Aluigi, M. G., Guida, C., and Falugi, C. (2010). Apoptosis as a specific biomarker of diazinon toxicity in NTera2-D1 cells. Chem. Biol. Interact. 187, 299-303.

Amaroli, A., Trielli, F., Bianco, B., Giordano, S., Moggia, E., and Corrado, M. U. (2005). Effects of time-variant extremely lowfrequency (ELF) electro-magnetic fields (EMF) on cholinesterase activity in Dictyostelium discoideum (Protista). Chem. Biol. Interact. 157-158, 355-356.

Anderson, A. A., Ushakov, D. S., Ferenczi, M. A., Mori, R., Martin, P., and Saffell, J. L. (2008). Morphoregulation by acetylcholinesterase in fibroblasts and astrocytes. J. Cell. Physiol. 215, 82-100.

Angelini, C., Aluigi, M. G., Sgro, M., Trombino, S., Thielecke, H., and Falugi, C. (2005). Cell signalling during sea urchin development: a model for assessing toxicity of environmental contaminants. Prog. Mol. Subcell. Biol. 39, 45-70.

Angelini, C., Baccetti, B., Piomboni, P., Trombino, S., Aluigi, M. G.,
Stringara, S., Gallus, L., and Falugi, C. (2004). Acetylcholine synthesis and possible functions during sea urchin development. Eur. J. Histochem. 49, 235-244.

Angelini, C., Costa, M., Morescalchi, F., Cimoli, G., Coniglio, L., and Falugi, C. (1998). Muscarinic drugs affect cholinesterase activity and development of eye structures during early chick development. Eur. J. Histochem. 42, 309-320.

Baker, P. F., and Presley, R. (1971). Promotion of polyspermy in the sea urchin egg by nicotine and its antagonism by curare. J. Physiol. 213, 62P-63P.

Barbash, S., and Soreq, H. (2012). Threshold-independent metaanalysis of Alzheimer's disease transcriptomes shows progressive changes in hippocampal functions, epi-genetics and microRNA regulation. Curr. Alzheimer Res. [Epub ahead of print]. (2004). The adhesive role of acetylcholinesterase (AChE): detection of AChE binding proteins in developing rat spinal cord. Neurochem. Res. 29, 2043-2050.

Bustos-Obregón, E., and GonzálezHormazabal, P. (2003). Effect of a single dose of malathion on spermatogenesis in mice. Asian J. Androl. 5, 105-107.

Buznikov, G. A. (1980). "Biogenic monoamines and acetylcholine in protozoa and metazoan embryos," Aspects, eds J. Salanki and M. Turpaev (Budapest: Akademial Kiado), 7-28.

Buznikov, G. A. (1990). "Neurotransmitters in embryogenesis," in Physiology and General Biology, Section F of Series, ed T. M. Turpaev (Harwood, London: Soviet Scientific Reviews). 1-350.

Buznikov, G. A., Nikitina, L. A., Bezuglov, V. V., Lauder, J. M., Padilla, S., and Slotkin, T. A. (2001). An invertebrate model of the developmental neurotoxicity of insecticides: effects of chlorpyrifos and dieldrin in sea urchin embryos
Bigbee, J. W., and Sharma, K. V. in Neurotransmitters: Comparative

alternative proteins from the same gene, and may help to shed light on the evolutive history of AChE molecules and of the cholinergic system.

\section{ACKNOWLEDGMENTS}

Most of the experiments were carried out between 2002 and 2005 thank to an EC grant to the SENSPESTI, EC K4-2002-02264 project and during the ongoing INESE project (IIT seed project).

and larvae. Environ. Health Perspect. $109,651-661$

Buznikov, G. A., Nikitina, L. A., Rakić L. M., Milosevic, I., Bezuglov, V. V., Lauder, J. M., and Slotkin, T. A. (2007). The sea urchin embryo, an invertebrate model for mammalian developmental neurotoxicity, reveals multiple neurotransmitter mechanisms for effects of chlorpyrifos: therapeutic interventions and a comparison with the monoamine depleter, reserpine. Brain Res. Bull. 74, 221-231.

Buznikov, G. A., Sakharova, A. V., Manukhin, B. N., and Markova, L. N. (1972). The role of neurohumors in early embryogenesis. IV. Fluorimetric and histochemical study of serotonin in cleaving eggs and larvae of sea urchins. J. Embryol. Exp. Morphol. 27, 339-351.

Buznikov, G. A., and Shmukler, Y. B. (1978). Effect of antimediator preparations on the intercellular relations in early embryos of the sea urchin. Ontogenez 9, 173-178.

Buznikov, G. A., and Shmukler, Y. B. (1981). Possible role of "prenervous" neurotransmitters in cellular interactions of early embryogenesis: a hypothesis. Neurochem. Res. 6 , 55-68.

Buznikov, G. A., Shmukler, Y. B., and Lauder, J. M. (1996). From oocyte to neuron: do neurotransmitters function in the same way throughout development? Cell. Mol. Neurobiol. $16,533-559$.

Canesi, L., Negri, A., Barmo, C., Banni, M., Gallo, G., Viarengo, A., and Dondero, F. (2011).The organophosphate Chlorpyrifos interferes with the responses to $17 \beta$-estradiol in the digestive gland of the marine mussel Mytilus galloprovincialis. PLoS One 6:e19803. doi: 10.1371/journal.pone.0019803

Cangialosi, M. V., Puccia, E., Mansueto, V., and D'Agati, P. (2006). Histochemical localization of acetylcholinesterase activity in ovary and embryos of Ciona intestinalis and Ascidia malaca (Ascidiacea, Urochordata) after exposition to trybutyltin-chloride. Caryologia 59, 366-370.
Cariello, L., Romano, G., and Nelson, L. (1986). Acetylcholinesterase in sea urchin spermatozoa. Gamete Res. $14,323-332$.

Casas, E., Bonilla, E., Ducolomb, Y., and Betancourt, M. (2010). Differential effects of herbicides atrazine and fenoxapropethyl, and insecticides diazinon and malathion, on viability and maturation of porcine oocytes in vitro. Toxicol. In Vitro 24, 224-230.

Catalano, J. (2007). Mechanisms of Neurotoxicity of Organophosphates, Carbamates, and Alkylating Agents. Ph.D. dissertation, University of Maryland, Baltimore.

Chakraborty, J., and Nelson, L. (1976). Comparative study of cholinesterases distribution in the spermatozoa of some mammalian species. Biol. Reprod. 15, 579-585.

Chanda, S. M., and Pope, C. N. (1996). Neurochemical and neurobehavioral effects of repeated gestational exposure to chlorpyrifos in maternal and developing rats. Pharmacol. Biochem. Behav. 53, 771-776.

Coniglio, L., Morale, A., Angelini, C., and Falugi, C. (1998). Cholinergic activation of settlement in Ciona intestinalis metamorphosing larvae. J. Exp. Zool. 280, 314-320.

Contreras, H. R., Paredes, V., Urquieta, B., Del Valle, L., and BustosObregòn, E. (2006). Testosterone production and spermatogenic damage induced by organophosphorate pesticides. Biocell 30, 423-429.

Delmonte Corrado, M. U., Ognibene, M., Trielli, F., Politi, H., Passalacqua, M., and Falugi, C. (2002). Detection of molecules related to the GABAergic system in a single-cell eukaryote, Paramecium primaurelia. Neurosci. Lett. 329, 65-68.

Delmonte Corrado, M. U., Politi, H., Trielli, F., Angelini, C., and Falugi, C. (1999). Evidence for the presence of a mammalian-like cholinesterase in Paramecium primaurelia (Protista, Ciliophora) developmental cycle. J. Exp. Zool. 283, 102-105.

de Oliveira, P., Gomes, A. Q., Pacheco, T. R., de Almeida, V. 
V., Saldanha, C., and Calado, A. (2012). Cell-specific regulation of acetylcholinesterase expression under inflammatory conditions. Clin. Hemorheol. Microcirc. [Epub ahead of print].

Drews, U. (1975). Cholinesterase in embryonic development. Prog. Histochem. Cytochem. 7, 1-52.

Ducolomb, Y., Casas, E., Valdez, A., González, G., Altamirano-Lozano, M., and Betancourt, M. (2009). In vitro effect of malathion and diazinon on oocytes fertilization and embryo development in porcine. Cell Biol. Toxicol. 25, 623-633.

Edwards, J. A., and Brimijoin, S. (1983). Thermal inactivation of the molecular forms of acetylcholinesterase and butyrylcholinesterase. Biochim. Biophys. Acta 742, 509-516.

Epel, D. (1980). Ionic triggers in the fertilisation of sea urchin eggs. Ann. N.Y. Acad. Sci. 339, 74-85.

Falugi, C. (1993). Localization and possible role of molecules associated with the cholinergic system during "non-nervous" developmental events. Eur. J. Histochem. 37, 287-294.

Falugi, C., Aluigi, M. G., Chiantore, M. C., Privitera, D., Ramoino, P., Gatti, M. A., Fabrizi, A., Pinsino, A., and Matranga, V. (2012). Toxicity of metal oxide nanoparticles in immune cells of the sea urchin. Mar. Environ. Res. 76, 114-121.

Falugi, C., Collodel, G., Moretti, E., Piomboni, P., Aluigi, M. G., Angelini, C., and Baccetti, B. (2008). "A neural-like model for sperm-egg interactions. Involvement of the cholinergic System," in Sperm Morphology and Pathology, eds G. Collodel and E. Moretti (Kerala: Research Signpost press), 1-16.

Falugi, C., Grattarola, M., and Prestipino, G. (1987). Effects of lowintensity pulsed electromagnetic fields on the early development of sea urchins. Biophys. J. 51, 999-1003.

Falugi, C., Morri, C., Bouillon, J., and Boero, F. (1994). Localization of some neurotransmitters during development in hydroidomedusae. Tissue Cell 26, 523-538.

Falugi, C., Pieroni, M., and Moretti, E. (1993). Cholinergic molecules and sperm functions. J. Submicrosc. Cytol. Pathol. 25, 63-69.

Falugi, C., and Raineri, M. (1985). Acetylcholinesterase (AChE) and pseudocholinesterase (BuChE) activity distribution pattern in early developing chick limbs. J. Embryol. Exp. Morphol. 86, 89-108.

Fluck, R. A., and Shih, T.-M. (1981). Acetylcholine in embryos of
Oryzias latipes, a teleost: gas chromatographic-mass spectrometric assay. Comp. Biochem. Physiol. C Comp. Pharmacol. 70, 129-130.

Fluck, R. A., Wynshaw-Boris, A. J., and Schneider, L. M. (1980). Cholinergic molecules modify the in vitro behavior of cells from early embryos of the medaka Oryzias latipes, a teleost fish. Comp. Biochem. Physiol. C. 67C, 29-34.

Geyer, B. C., Woods, R. R., and Mor, T. S. (2008). Increased organophosphate scavenging in a butyrylcholinesterase mutant. Chem. Biol. Interact. 175, 376-379.

Giordano, C., G. Poiana, G., AugustiTocco, G., and Biagioni, S. (2007). Acetylcholinesterase modulates neurite outgrowth on fibronectin. Biochem. Biophys. Res. Commun. 356, 398-404.

Hanin, G., and Soreq, H. (2011) Cholinesterase-targeting microRNAs identified in silico affect specific biological processes. Front. Mol. Neurosci. 4:28. doi: 10.3389/fnmol.2011.00028

Hayes, W. J. Jr., and Laws, E. R. Jr. (1991). "Organic phosphorous pesticides," in Handbook of Pesticide Toxicology, eds W. J. Hayes and E. R. Laws (San Diego, CA: Academic Press). 133-134.

Inkson, C. A., Brabbs, A. C., Grewal, T. S., Skerry, T. M., and Genever, P. G. (2004). Characterisation of acetylcholinesterase expression and secretion during osteoblast differentiation. Bone 35, 819-827.

Ivonnet, P. I., and Chambers, E. L. (1997). Nicotinic acetylcholine receptors of the neuronal type occur in the plasma membrane of sea urchin eggs. Zygote 5, 277-287.

Johnson, G., and Moore, S. W. (2007). Acetylcholinesterase readthrough peptide shares sequence similarity to the 28-53 peptide sequence of the acetylcholinesterase adhesionmediating site and competes for ligand binding in vitro. J. Mol. Neurosci. 31, 113-126.

Johnson, G., Swart, C., and Moore, S. W. (2008). Interaction of acetylcholinesterase with the G4 domain of the laminin alphal-chain. Biochem. J. 411, 507-514.

Karczmar, A. G. (1970). "Introduction," in Anticholinesterase Agents, vol. 1, Sect. 13 of International Encyclopaedia of Pharmacology and Therapeutics, ed A. G. Karczmar (Oxford, NY: Toronto, Sydney, Braunschweig: Pergamon Press), 1-35.

Karnovsky, M. J., and Roots, L. (1964). A "direct colouring" thiocholine method for cholinesterase. J. Histochem. Cytochem. 12, 219-221.

Le Douarin, N. M. (1986). Investigations on the neural crest. Methodological aspects and recent advances. Ann. N.Y. Acad. Sci. 486, 66-86.

Liang, D., Blouet, J. P., Borrega, F., Bon, S., and Massoulié, J. (2009). Respective roles of the catalytic domains and C-terminal tail peptides in the oligomerization and secretory trafficking of human acetylcholinesterase and butyrylcholinesterase. FEBS J. 276, 94-108.

Massoulié, J., Pezzementi, L., Bon, S., Krejci, E., and Vallette, F. M. (1993). Molecular and cellular biology of cholinesterases. Prog. Neurobiol. 41, 31-91.

Massoulié, J., Perrier, N., Noureddine, H., Liang, D., and Bon, S. (2008). Old and new questions about cholinesterases. Chem. Biol. Interact. $175,30-44$.

Meerson, A., Cacheaux, L., Goosens, K. A., Sapolsky, R. M., Soreq, H., and Kaufer, D. (2010). Changes in brain MicroRNAs contribute to cholinergic stress reactions. J. Mol. Neurosci. $40,47-55$.

Mineau, P. (1991). Cholinesterase Inhibiting Insecticides. Their Impact on Wildlife and Environment Vol II. Chemicals in Agriculture. Amsterdam: Elsevier.

Minganti, A., and Falugi, C. (1980). An epithelial localization of acetylcholinesterase in the ascidian Ciona intestinalis embryos and larvae. Acto Embryol. Morphol. Exp. 1, 143-155.

Minganti, A., Falugi, C., Raineri, M., and Pestarino, M. (1981). Acetylcholinesterase in the embryonic development: an invitation to a hypothesis. Acta Embryol. Morphol. Exp. 2, 30-31.

Minganti, A., Falugi, C., Raineri, M., and Ricci, A. (1975). Histochemical Researches on Artemia Salina Larvae. Acta Embryologiae Experimentalis. Italy: Gruppo Embriologico Italiano. Riunione 21 March, Milan.

Mor, I., Bruck, T., Greenberg, D. Berson, A., Schreiber, L., Grisaru, D., and Soreq, H. (2008a). Alternate AChE-R variants facilitate cellular metabolic activity and resistance to genotoxic stress through enolase and RACK1 interactions. Chem. Biol. Interact. 175, 11-21.

Mor, I., Sklan, E. H., Podoly, E., Pick, M., Kirschner, M., Yogev, L. Bar-Sheshet Itach, S., Schreiber, L., Geyer, B., Mor, T., Grisaru, D., and Soreq, H. (2008b). Acetylcholinesterase- $\mathrm{R}$ increases germ cell apoptosis but enhances sperm motility. J. Cell. Mol. Med 12, 479-495.

Nelson, L. (1964). Acetylcholinesterase in Bull Spermatozoa. J. Reprod. Fertil. 7, 65-71.

Nelson, L. (1978). Chemistry and neurochemistry of sperm motility control. Fed. Proc. 37, 2543-2547.

Nelson, L. (1990). Pesticide perturbation of sperm cell function. Bull. Environ. Contam. Toxicol. 45, 876-882.

Nelson, L., McGrady, V., and Fangboner, M. E. (1970). "Control of flagellar movement," in Comparative Spermatology, ed B. Baccetti (New York, NY: Academic Press), 465-478.

Ohta, K., Takahashi, C., and Tosuji, H. (2009). Inhibition of spicule elongation in sea urchin embryos by the acetylcholinesterase inhibitor eserine. Comp. Biochem. Physiol. B Biochem. Mol. Biol. 153, 310-316.

Okamura, A., Kamijima, M., Ohtani, K., Yamanoshita, O., Nakamura, D. Ito, Y., Miyata, M., Ueyama, J., Suzuki, T., Imai, R., Takagi, K., and Nakajima, T. (2009). Broken sperm, cytoplasmic droplets and reduced sperm motility are principal markers of decreased sperm quality due to organophosphorus pesticides in rats. J. Occup. Health. 51, 478-487.

Perry, M. J. (2008). Effects of environmental and occupational pesticide exposure on human sperm: a systematic review. Hum. Reprod. Update 14, 233-242.

Pesando, D., Huitorel, P., Dolcini, V., Angelini, C., Guidetti, P., and Falugi, C. (2003). Biological targets of neurotoxic pesticides analysed by alteration of developmental events in the Mediterranean sea urchin, Paracentrotus lividus. Mar. Environ. Res. 55, 39-57.

Pezzementi, L., and Chatonnet, A. (2010). Evolution of cholinesterases in the animal kingdom. Chem. Biol. Interact. 187, 27-33.

Pezzementi, L., Nachon, F., and Chatonnet, A. (2011). Evolution of acetylcholinesterase and butyrylcholinesterase in the vertebrates: an atypical butyrylcholinesterase from the Medaka Oryzias latipes. PLoS One 6:e17396. doi: 10.1371/ annotation/938a4e59-a5d1-448c-b7 c1-632bf9e7e8ef

Piomboni, P., Baccetti, B., Moretti, E., Gambera, L., Angelini, C., and Falugi, C. (2001). Localisation of molecules related to cholinergic signalling in eggs and zygotes of the sea urchin, Paracentrotus lividus. J. Submicrosc. Cytol. Pathol. 33, 187-193. 
Placzek, M., Jessell, T. M., and Dodd, J. (1993). Induction of floor plate differentiation by contact-dependent, homeogenetic signals. Development 117, 205-218.

Raineri, M., and Modenesi, P. (1986). Preliminary evidence for a cholinergic-like system in lichen morphogenesis. Histochem. J. 18, 647-657.

Raineri, M., and Modenesi, P. (1988). Membrane-bound $\mathrm{Ca}^{2+}$ distribution visualized by chlorotetracycline fluorescence during morphogenesis of soredia in a lichen. Histochem. J. 20, 81-87.

Ravera, S., Falugi, C., Calzia, D., Pepe, I. M., Panfoli, I., and Morelli, A. (2006). First cell cycles of sea urchin Paracentrotus lividus are dramatically impaired by exposure to extremely low-frequency electromagnetic field. Biol. Report. 75, 948-953.

Rakonczay, Z., and Papp, H. (2001). Effects of chronic metrifonate treatment on cholinergic enzymes and the blood-brain barrier. Neurochem. Int. 39, 19-24.

Robitzki, A., Mack, A., Hoppe, U., Chatonnet, A., and Layer, P. G. (1998). Butyryl-cholinesterase antisense transfection increases apoptosis in differentiating retinal re-aggregates of the chick embryo. J. Neurochem. 71, 413-420.

Romero, P., Barnett, P. G., and Midtling, J. E. (1989). Congenital anomalies associated with maternal exposure to oxydemeton-methyl. Environ. Res. 50, 256-261.
Sawyer, C. H. (1943). Cholinesterase and the behavior problem in amblystoma. I. The relationship between the development of the enzyme and early motility. II. The effects of inhibiting cholinesterase. J. Exp. Zool. 92, 1-33.

Shaked, I., Meerson, A., Wolf, Y., Avni, R., Greenberg, D., GilboaGeffen, A., and Soreq, H. (2009). MicroRNA-132 potentiates cholinergic anti-inflammatory signaling by targeting acetyl-cholinesterase. Immunity 31, 965-973.

Shmukler, Y. B. (1981). Cellular interactions in early sea urchin embryo. III. Influence of neuropharmaca on the cleavage pattern of Scaphechinus mirabilis half-embryos. Ontogenez 12, 404-409.

Shmukler, Y. B. (1993). Possibility of membrane reception of neurotransmitter in sea urchin early embryos. Comp. Biochem. Physiol. C. 106, 269-273.

Shmukler, Y. B., Chailakhyan, L. M., Smolyaninov, V. V., Bliokh, Zh. L., Karpovich, A. L., Gusareva, E. V., Naidenko, T. Kh., Khashaev, Z. Kh.M., and Medvedeva, T. D. (1981). Cellular interactions in early sea urchin embryo. II. Dated mechanical blastomere isolation. Ontogenez 12, 398-403.

Sklan, E. H., Lowenthal, A., Korner, M., Ritov, Y., Landers, D. M., Rankinen, T., Bouchard, C., Leon, A. S., Rice, T., Rao, D. C., Wilmore, J. H., Skinner, J. S., and Soreq, H. (2004). Acetylcholinesterase/paraoxonase genotype and expression predict anxiety scores. In: health, risk factors, exercise training, and genetics study. Proc. Natl. Acad. Sci. U.S.A. 101, 5512-5517.

Sperling, L. E., Steinert, G., Boutter, J., Landgraf, D., Hescheler, J. Pollet, D., and Layer, P. G. (2008). Characterization of cholinesterase expression during murine embryonic stem cell differentiation. Chem. Biol. Int. 175, 156-160.

Stacy, A. R., Diggle, S. P., and Whiteley, M. (2011). Rules of engagement: defining bacterial communication. Curr. Opin. Microbiol. 15, 155-161.

Thunnissen, F. B. (2009). Acetylcholine receptor pathway and lung cancer. $J$. Thor. Oncol. 4, 943-946.

Weinberger, C., Penner, P. L., and Brick, I. Y. (1984). Polyingression, an important morphogenetic movement in chick gastrulation. Am. Zool. 24, 545-554.

Whittaker, J. R., Ortolani, G., and Farinella-Ferruzza, N. (1977) Autonomy of acetylcholinesterase differentiation in muscle lineage cells of ascidian embryos. Dev. Biol. 55, 196-200.

Wessler, I., and Kirkpatrick, C. J. (2008). Acetylcholine beyond neurons: the non-neuronal cholinergic system in humans. Br. J. Pharmacol. 154, 1558-1571.

Youngstrom, K. A. (1938). On the relationship between cholinesterase and the development of behavior in amphibia. J. Neurophysiol. 1, 357.

Yucra, S., Gasco, M., Rubio, J., and Gonzales, G. F. (2008). Semen quality in Peruvian pesticide applicators: association between urinary organophosphate metabolites and semen parameters. Environ. Health. 7,59

Zhang, X. J., Yang, L., Zhao, Q., Caen, J. P., He, H. Y., Jin, Q. H., Guo, L. H., Alemany, M., Zhang, L. Y., and Shi, Y. F. (2002). Induction of acetyl-cholinesterase expression during apoptosis in various cell types. Cell Death Diff. 9, 790-800.

Zhu, B. K., Wang, P., Zhang, X. D. Jiang, C. C., Li, H., Avery-Kiejda, K. A., Watts, R., and Hersey, P. (2008). Activation of Jun N-terminal kinase is a mediator of vincristine-induced apoptosis of melanoma cells. Anticancer Drugs 19, 189-200.

Conflict of Interest Statement: The authors declare that the research was conducted in the absence of any commercial or financial relationships that could be construed as a potential conflict of interest.

Received: 28 January 2012; accepted: 02 April 2012; published online: 20 April 2012.

Citation: Falugi $C$ and Aluigi MG (2012) Early appearance and possible functions of non-neuromuscular cholinesterase activities. Front. Mol. Neurosci. 5:54. doi: 10.3389/fnmol.2012.00054

Copyright (c) 2012 Falugi and Aluigi. This is an open-access article distributed under the terms of the Creative Commons Attribution Non Commercial License, which permits non-commercial use, distribution, and reproduction in other forums, provided the original authors and source are credited. 